https://doi.org/10.29013/ESR-20-5.6-85-89

Satimova Dilafruz Numonjonovna, Scientific researcher, Andijan State University Faculty of Foreign Languages E-mail:mrs.secret96@mail.ru

\title{
APPROACHES TO UZBEK SLANG AND ITS TYPE: YOUTH AND GENERAL SLANG
}

\begin{abstract}
The present article is concerned with the developing of slangs and different approaches to types of slang in Uzbek. Furthermore, it deals with the development of active term "slang" in sociolect by young generation. The role and function of Youth slang are given in social layer within comparing world linguistic views on the types of slang. As Youth slang is commonly used and created by young people in Uzbek, it is considered to be a dominant factor inside of Slang itself. Some interesting examples of slang are highlighted from communication among Uzbek people.

Keywords: sociolect, non-standard system, jargon, argot, cant, social layer, emotionally- expressive, age- restricted, phonetic mimicry, socio-psycholinguistic.

The literature on slang has been extensively developed in English and Russian linguistics including dictionaries, scholar works and articles. In XXI century a concern in slangs is being attracted by Uzbek scholars as well. In Uzbek linguistics, active terms of sociolect "jargon" and "argot" are a part of the lexical structure of the modern Uzbek literary language, with the exception of "slang" term. All of the following non-standard systems of language have not been studied by Uzbek linguists yet, whereas the usage of slang among youth is growing rapidly day by day. It is known that these trios can be found as separate word units in English dictionaries. Basically, slang has come from English language into linguistics, therefore its definition can be found a lot in English and American dictionaries. Regardless of the fact that, some dictionaries refer to "jargon" and "argot" as synonyms for "slang" [9], on the other hand it is defined by its individual order of interpretation, for instance, in the Macmillan English Dictionary, slang is defined as follows [5, 1401]:

Words or expressions that are very informal and are not considered suitable for more formal situations. Some slang is used only by a particular group of people.

While it is true to say that the transition and adaptation of one stylistic layer to another is so unstable and disobedient, that it so complex and difficult to comprehend that it is impossible to draw a line between them and put constraint in non-literary linguistics. "Slang", "jargon" and "argot" are often confused because of their functional closeness in oral communication. Therefore, distinguishing them by language poses is a problem not only for users but also for professional lexicographers $[4,20]$. Mostly these three terms (slang jargon, argot) are frequently discussed together in general linguistics, and their other siblings, "cant" is considered coupled with them. Although "cant" has lost its essence in modern linguistics, it is explained as the emergence and origination of slang by the scholars' point of view. In most sources, slang is referred to as street language and has been given several definitions by many linguists. The comments reflect both positive and negative points. Almost every prominent language expert has given his or her own persuasive definition for slang, and some well-known slang scholars have advocated the essence and methods of understanding it.

The eminent scholar of slang E. Partridge suggests the following logical understanding of the phenom-
\end{abstract}


enon: "Slang is much rather than spoken a literary language. It originates, nearly always, in speech. To coin a term on a written page is almost inevitably to brand it as a neologism which will either be accepted or become a nonce- word (or phrase), but, except in the rarest instances that term will not be slang" $[10,3-6]$.

The author of many works on this field, I. R. Galperin, denies that slang is stable as separate linguistic phenomenon. He claimed that if the term "slang" serves as an autonomous category in linguistics, it is indispensible to look carefully at the words in it and distinguish them from jargon, dialect, professionalism and commonly used words [1, 107-114]. But the linguist V.A. Khomyakov strongly disagrees: "This view seems a bit nihilistic, as it sums up the tremendous work of many generations of scholars who have studied slang and leaves no doubt as to the existence of slang in the early stages of English language development. Even the slang proved viable itself. Even in other languages, it has been used to refer to a certain layer of vocabulary and phraseology, which has retained all its synonyms" [2, 34]. I.R. Galperin's argument was not sufficiently developed and could not provide a basis for it in his later works. To our way of thinking, it is requisite to capture attention not only to which arguments about the term are precise, but also to its use in oral speech and to the needs of the society in relation to it. Thus, the consideration of the issue must be taken so as to require a serious approach.
Well-known Soviet researcher V.G. Vilyuman, who wrote several articles on the properties of slang, applied the division of slang into two groups: General slangs are words and phrases that are common in colloquial speech, generally understood and widely spoken, but beyond the boundaries of English literary dictionaries, vividly expressive, emotionally-evaluative coloring, expressing novelty and originality, as well as stylistic synonyms of literary language words in these features. Special slangs, i.e. words and phrases included in special or professional vocabulary: sailors, military, athletes, actors, lawyers, students, etc., local dialect, words and phrases used in narrow groups, as well as argot, social jargon $[13,137]$.

Linguist V. A. Khomyakov, who demanded that these views be further explored on the slang, clarified the confusion on the slang with his views, shedding light on V. G. Vilyuman's classification of the slang. We can say that the description given to the General slang by the linguist is slightly different from views of V. G. Vilyuman. As he considers: The General slang is relatively stable for a certain period, a widespread and generally understood social speech micro system in colloquial terms, very heterogeneous in its genetic composition and degree of approximation to familiar speaking, with a pronounced emotionally expressive a connotation of vocabulary, often representing a mockery of social, ethical, aesthetic, linguistic and other conventions and authorities $[2,39]$.

Approaches to General slang:

\begin{tabular}{|l|l|}
\hline \multicolumn{1}{|c|}{ V.G. Vilyuman } & \multicolumn{1}{c|}{ V.A. Khomyakov } \\
\hline $\begin{array}{l}\text { beyond the boundaries of English literary } \\
\text { dictionaries }\end{array}$ & relatively stable for a certain period \\
\hline stylistic synonyms ofliterary language words & emotionally expressive \\
\hline expressing novelty and originality & representing a mockery of social, ethical, aesthetic, linguistic \\
\hline
\end{tabular}

Researcher recognizes general and special slang as integral part of the concept of "slang" with notifying them a two-sided individual interpretation. The function that connects each other is that with the help of one the vocabulary of the other expands. It can be understood that the general slang component is enriched at the expense of the special slang. It should be noted that such a statement by the linguist V.A. Khomyakov, the mutual function of the two slangs is clarified very perspicuously. However, in our opinion, it is unsuitable to give jargon, argot, and dialectics into the Special Slang. This classification provides a meaningful 
and detailed account of the expert's initial views on the role of slang in the speech layer. Nonetheless, we think that the phenomenon is divided into two types, and the aggregation of all words and phrases of different nature in oral speech within one term is somewhat indifferent by linguists. As proof of our point, we can cite below a number of linguists who have elaborated on their views on the subject. This generally accepted differentiation is criticized by M.M. Maykovsky. The author takes such an approach that "slang as jargon never belonged to narrow social groups and it never performed the secret function of particular professional community. Thus, the main feature of slang is that it is common to all social groups of native speakers, so it is inappropriate to distinguish between general and special slang. In the second case, it is often about another type of slang" $[8,23]$. The argument of the Indo-European linguist is, in our opinion, a very plausible one. Unfortunately, the linguist's point of view is not sufficiently substantiated.

Elise Matiello, a young scientist at the University of Pisa, conducted her first study on English slang. We can evaluate this issue as the most accurate and comprehensive classification: "Slang differs from jargon in its lack of prestige and pretentiousness. In fact, slang terminology is much more familiar and spontaneous than the technical jargon of science, medicine, academics, law bureaucracy, business, etc. Slang may be used within a particular group like musicians, doctors, soldiers or seamen, but it does not exactly deal with status or reputation" $[6,36]$. From this it can be understood that slang is a unit that easier to understand than jargon. Jargon is a word within a profession that only those who work on that field can understand its essence. Linguist V.N. Yarseva: Argot is a special criminal language, unlike slang and jargon, which consists of arbitrarily selected mutated elements of one or more natural languages of a very narrow and limited professional or social group, keeping the subject secret from communication [12, 43].

According to our way of thinking, linguists need to take a comprehensive approach to this debatable statement. Fundamentally, the slang carriers are young people, making it an element of pop culture that is considered necessary for prestige and selfexpression $[7,35]$ It is estimated that the creators of slang are youth, as well as those who promote slang to the public. At this point, we decided that the slang content should be divided into two groups in Uzbek language:1. Youth slang (YS) 2. General slang (GS)

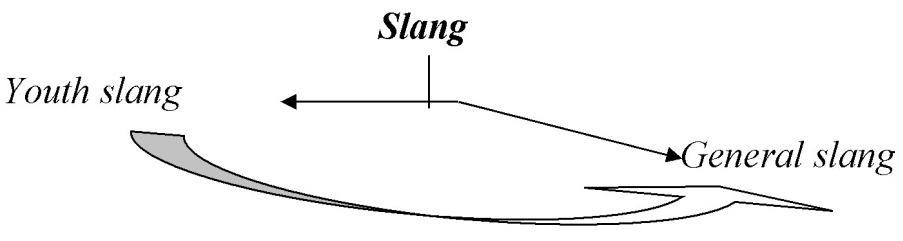

Image highlights the fact that GS are mostly build up by young members of society and are widely used as they are passed onto other users of social layer. Thus, YS is the dominant unit in the slang structure enriching GS vocabulary. From a sociolinguistic point of view, there is an unnoticeable difference between YS and GS units. The native speakers of English interpret the second concept as words and phrases that are widely understood and used in colloquial speech, figuratively, emotionally-evaluative, expressing their originality, constantly served as synonyms for literary words. We also understand daily used vocabulary and phraseology, which have descriptive-expressive and basic emotional functions, when we say the general slang in the wide range mentioned above. In order to avoid subjective interpretations, the GS as a lexicalphraseological layer of spoken language, according to V.A. Khomyakov, has a number of features $[2,39]$. The use of slang, which is a daily lexicon, is observed mainly in the homeland of slang England and America. In the Uzbek language, due to the development of society and socio-economic changes in the XXI century influenced for demanding of GS words and phrases extensively, which are now emotionally evaluative by population of the country.

The main differences between youth slang and youth jargon are that youth slang has a vast range of social connotations in line with GS characteristics, is brightly expressed emotionally-expressive, humor- 
ous, and is used by people of different ages in social strata. The characteristics of youth jargon, on the other hand, are comprehensible in a limited area belonging to a narrower group of individuals, and therefore, in addition to fatal intentions in relation to its members can express and hostility towards "strangers" [11,59]. Youth slang, as mentioned above, is more pliant to dissimilar age social group with the reason why so intensive. Unlike jargon, slang has no professional limitations (young people are not just a group of people united by occupation, this is a large social group), its use is more likely indicates a certain cultural position of the speaker, i.e. slang-this is a "phenomenon of a peculiar attitude performing world outlook and ideological functions $[11,60]$.

In the sociolinguistic approach to the study of YS, slang users are no doubt asked the question of setting an age limit. To this end, we also found it necessary to set the age limits for the YS below, based on the materials of the researchers of "Modern Russian Youth Slang" A. Yu. Ramanov. It is noteworthy that issue was developed by Russian linguists. To study the age-related differences in human language behaviors, sociolinguists define a group of language users according to their biological and chronological age in terms of speech.(e.g., 15-20, 20-25, 25-30 years old, etc.) "Completion of formal education, stable employment, family and children, naturally, this happens at different ages for different people, but on average, changes in family and work status in Russia occur at the age of 23-30. From around this age, obviously, language behavior should begin to alter", admits the linguist. Moreover, in his sociolinguistic survey, it was discovered that the age group of 13 to 14 year olds is mainly the creators of slang. M.M. Kopylenko mentioned that youth jargon is used in communication between people aged 14-25 [3, 48]. Based on the over approaches and observations, we can say that YS is multi-faced word and phrase that is used in free communication between people aged 13-30. It has been ascertained that individuals over the age of 30 tend to display more aspirations for literary language norms in their speech, but they also use slang in order to bring a sense of humor to their communication (as well as a number of slang-specific features). In this case, they use slang, i.e. YS, invented and broadly used by youngsters. In Uzbek language there are several YS which are borrowed from English language, as we can call them borrowing slang words:

- пати- party (зиёфат), фаворит- favourite (севимми), гугле-google (қилирув хизмати), респектrespect (хурмат), чики-чики-Cheeky-cheeky (зўр), фолмоверларимиз-followers-(кузатувчикар), юзерлар-users-(фойдаланувчимар).

In the method of phonetic mimicry, the pronunciation of assimilated words through semantically similar aspects with commonly used words. Such words are mainly active in Russian and are formed by comparing words derived from English. Needless to say, in Uzbek, a number of such slangs can be found, adapted to the common word in the acquired language: Шароит - Share it

An English word expression Share it [ $\int e$ I $t$ ] has a bit different pronunciation for Uzbek users, therefore it was compared to another literary word in the language keeping meaning in English. If we look at the lexeme of "Шароит" in the "Explanatory dictionary of the Uzbek language”: Шароит [шартлар, тартиб қоидалар] 1. Объектив холдаги муайян вазият. 2. Бироз нарсанинг воқеаланишига таъсир этувчи холат, вазият, имконият.

Шароит [conditions, rules] 1.A specific situation in the objective state. 2. A situation, circumstance, opportunity that affects the occurrence of something.

Uzbek slang "шароит" is a program installed on the phone, which usually serves to transfer several functions such as photos, videos, software, and so on. It is used in oral speech as follows: (In conversation) 1) Шароитингни ёқдингми? Расмиарни юборяпман. 2) Шароитинг борми? Зўр нарса ташлайман.

As we can see, the user can fit it borrowings to a commonly used word if it is arduous to pronounce.

Furthermore, as a result of our studies within the GS, the YS should also be worthy of its own character- 
istics, in which case we give it the following approach in Uzbek language: Slang is the language of (1) youth. It is kind of live communication to bring a spirit of novelty and modernity, to show fun and joy in order to move away from the old in exchange of information. It does not reflect any (2) bias and rude features. It is therefore genetically and functionally different from argot and vulgarism. (3) YS do not have professional limitations (this is large social group and not professional terms).This aspect is different from youth jargon. Due to time goes by, the vocabulary of YS will also be updated. Hence, its most significant feature (4) is novelty. Consequently, there exists a synonymy in slang. The old ones are replaced by new ones. Apart from this, it is characterized by semantic (5) humor. The context is used in the form of humor in order to avoid sadness and uninteresting atmosphere, and appear emotional- expressive conversation. It is a (6) word game of the younger generation a means to distinguish them from oldster. Furthermore, it has brightly expressed (7) emotional-evaluative character. It differs from the GS within (8) age-restriction, besides the vocabulary of GS enriches due to the YS, ergo it is a dominant unit in the slang structure. (9) There are 5 main functions of its creation. Consciously, the (10) socio-psycholinguistic approach is also stable in it, as it requires ingenuity and adroitness. Young generation have a vivid fantasy to build up new words and expressions outside of standard vocabulary. It is evident that there is recycling system in language as appearing new words and losing old ones. The obvious conclusion to be drawn is that it is worthy to scrutinize thoroughly of slangs in other sphere in modern Uzbek language as it is demand of usage them in social layer.

\section{References:}

1. Galperin I. R. About the term "slang" // Linguistic issues.-M: Academician of sciences - No. 6. 1956.P. 107-114.

2. Khomyakov V.A. Introduction to the study of slang- the main English colloquial language.- Vologda: Vologda state.ped.in-t, 1971.- 34 p.

3. Kopylenko M.M. The basics of ethnolinguistics.- Almat: Eurasia. 1995.- 48 p.

4. Lipatova A. T. Slang as a problem of sociolinguistics.- M.: Elpis. 2010.- 20 p.

5. Macmillan English Dictionary for Advanced Learners, London United Kingdom: Macmillan Publishers Limited, New Edition 2007.- 1401 p.

6. Matiello Elisa. An Introduction to English Slang.A Description of its Morphology.Semantics and Sociology. - Italy: Polimetrica International Scientific Publisher Monza. 2008.- 36 p.

7. Matyushenko E.E. Modern youth slang: Formation and functioning. The dissertation for the degree of candidate of philological sciences.- Volgograd: Voronezh State Pedagogical University. 2007.- 35 p.

8. Maykovsky M. M. English social dialects. Ontology, Structure, Etymology.- M.: Higher school. 1982.$23 \mathrm{p}$.

9. Merriam-Webster Dictionary. USA: Fogware Publishing Windows, 2000. Электронный словарь.

10. Partridge E., Slang Today and Yesterday.- London: Rout ledge \& Keg an Paul LTD, 1954.- P. 3-6.

11. Ukhova P. S. Structural and Semantic Characteristics of Student Slang. - Yaroslav: Diss. for the deg. of can. Phil. 2017.- 59 p.

12. Yartseva V.N. Linguistic Encyclopedic Dictionary.- M.: Big Russian Encyclopedia, 1998.- 43 p.

13. Vilyuman V. G. About ways of formation of slang words in modern English // Scientific notes of the Herzen State Pedagogical University, materials of "the Herzen Reading". - Vol. 111. - No. 6. 1960. P. $137-139$. 